\title{
Effect Of Processing Methods Of Bambara Groundnut Offal Diets On Haematology And Carcass Characteristics Of Broiler Finisher Chickens
}

\author{
L. N. Torhemen, B. M. Agabi, D. S. Adi and M. Torhemen
}

\begin{abstract}
The objective of the study was to evaluate the effect of two methods of processing Bambara Groundnut Offal (BGO), toasted and enzyme supplemented in broiler chicken diets on haematology and carcass characteristics of broiler finisher chicken. One hundred and eight (108) four- weeks- old unsexed commercial broiler chicks were divided into three groups $\left(\mathrm{T}_{1} 0 \% \mathrm{~T}_{2} 20 \% \mathrm{~T}_{3} 20 \%\right)$ of 36 birds, each replicated three times with 12 birds per replicate in a completely randomized design and fed for 28 days. Haematological parameters were not significantly $(\mathbf{p}>0.05)$ affected. Result of carcass characteristics showed that live weight, eviscerated weight, dressed weight, back weight, drumstick weight, breast weight, thigh weight and caecum weight were significantly $(p<0.05)$ affected. Birds fed enzyme supplemented BGO diets recorded higher weights compared with birds fed toasted BGO and the control diets. Other carcass characteristics such as wing weight, neck weight, head weight, shank weight and other internal organ characteristics were not significantly $(p>0.05)$ affected.

From the result, significant parameters have shown that birds fed bioenzyme supplemented BGO diets were superior to birds fed toasted BGO and the control diet. It is therefore recommended that $2 \mathrm{~g} / \mathrm{kg}$ bioenzyme supplemented BGO diet should be used at $20 \%$ BGO inclusion rate for finishing broiler chicken without adverse effect on the haematology and for increased carcass weight.
\end{abstract}

Index Terms - Bambara Groundnut Offal (BGO), Toasted BGO, Enzyme supplemented BGO, Haematology, Carcass characteristics.

\section{INTRODUCTION}

Poultry supplies the fast growing human population with high quality protein, contributes significantly to food security, poverty alleviation and ecologically sound management of natural resources [11]. In Nigeria, one of the greatest limitations of the expansion of the poultry industry is the high cost of feed ingredient [3]. It is therefore important to use unconventional materials like Bambara groundnut offal that are obtained at little or no cost.

Bambara groundnut offal (BGO) is a by-product of Bambara groundnut seeds processing. It is a sievate after extracting the flour for human use. It contains $14-24 \%$ crude protein [20], 20\% crude fibre, 5.36\% Ether extract, $41.64 \%$ nitrogen free extract.

Published on July 13, 2020

L. N. Torhemen, University of Agriculture Makurdi, Nigeria.

(corresponding e-mail: darlyn3x@yahoo.com)

B. M. Agabi, University of Agriculture Makurdi, Nigeria.

D. S. Adi, University of Agriculture Makurdi, Nigeria.

M. Torhemen, College of Agriculture Yandev, Nigeria.
The use of BGO in feeding monogastric animals like poultry is limited by its high fibre content and antinutritional factors [9], [10]). Processing methods such as toasting and or enzyme addition are known to reduce or eliminate the anti-nutrients in the material and improve digestibility of BGO based diets [4]. Enzyme supplementation is capable of disrupting the plant cell wall thereby enhancing nutrient absorption [1].

Blood profile examinations give the opportunity to investigate the presence of metabolites and other constituents in the body of the animal which play vital roles in the physiological, nutritional and pathological status of the animal [2], [6] and consequently the overall performance of the animal. The quality of carcass characteristics has direct relationship with nutrition as far as broiler production is concerned. This study was therefore conducted to evaluate the response of broiler finisher chickens to processing methods of BGO diets using hematological indices and carcass characteristics parameters.

\section{MATERIALS AND MethodS}

The experiment was carried out at the Poultry Section of the Livestock Unit, Teaching and Research Farm, Federal University of Agriculture, Makurdi Benue State Nigeria. Benue State is situated at the Southern Guinea Savannah belt of Nigeria. Makurdi is located on Latitude $7^{\circ} 43^{\prime} \mathrm{N}$ and Longitude $8^{\circ} 33^{\prime}$ E [15]. BGO used was obtained from Okpa sellers who process the bambara groundnut for the popular Okpa meal. The sievate was derived by grinding whole seeds of bambara groundnut and sieving it through $3.5 \mathrm{~mm}$ sieve. One portion of the BGO used was processed by toasting. One liter of water was added to $5 \mathrm{~kg}$ of BGO. The mixture was set over fire and stirred steadily to prevent it from sticking to the pan or burning for 40 minutes at a temperature of $100{ }^{\circ} \mathrm{C}$. This turned brownish and produced a sweet smelling aroma. This was allowed to cool before incorporating into the diets. The other portion of BGO was processed by adding $2 \mathrm{~g}$ bioenzyme per $1 \mathrm{~kg}$ BGO based diet and fed to the birds.

\section{A. Experimental diets}

Three isonitrogenous experimental diets $\mathrm{T}_{1} 0 \%, \mathrm{~T}_{2} 20 \%$ and $\mathrm{T}_{3} 20 \%$ were formulated as presented in Table 1. T1 contained $0 \%$ BGO, while $\mathrm{T} 2$ contained $20 \%$ toasted BGO and $\mathrm{T} 3$ contained $20 \%$ bioenzyme supplemented BGO at the rate of $2 \mathrm{~g}$ bioenzyme per kilogram $\mathrm{BGO}$ based diet. 
TABLE 1 INGREDIENT COMPOSITION OF BROILER FINISHER CHICKEN DiETS (G/100G). DIETARY TREATMENTS

\begin{tabular}{|c|c|c|c|}
\hline Level of BGO & 0\%BGO & $\begin{array}{c}20 \% \text { Toasted } \\
\text { BGO }\end{array}$ & $\begin{array}{l}20 \% \text { Enzyme } \\
\text { Added BGo }\end{array}$ \\
\hline Ingredients & $\mathbf{T}_{1}$ & $\mathbf{T}_{2}$ & $\mathbf{T}_{\mathbf{3}}$ \\
\hline Maize & 42.83 & 29.67 & 29.67 \\
\hline Full fat soybeans' & 37.77 & 30.93 & 30.93 \\
\hline Maize offal & 15.00 & 15.00 & 15.00 \\
\hline BGO & 0.00 & 20.00 & 20.00 \\
\hline Bone meal & 3.50 & 3.50 & 3.50 \\
\hline Salt & 0.40 & 0.40 & 0.40 \\
\hline Methionine & 0.25 & 0.25 & 0.25 \\
\hline Premix (Min/Vit) & 0.25 & 0.25 & 0.25 \\
\hline Bioenzyme & - & - & ++ \\
\hline Total & 100 & 100 & 100 \\
\hline \multicolumn{4}{|c|}{ Calculated Nutrients } \\
\hline Energy (kcal/kg) & $3,091.34$ & $2,901.36$ & $2,901.36$ \\
\hline Crude protein $(\%)$ & 20.00 & 20.00 & 20.00 \\
\hline Crude fibre $(\%)$ & 4.55 & 5.23 & 5.23 \\
\hline Ether Extract (\%) & 8.90 & 7.15 & 7.15 \\
\hline Calcium (\%) & 1.40 & 1.39 & 1.39 \\
\hline Phosphorus (\%) & 0.89 & 0.81 & 0.81 \\
\hline Lysine (\%) & 1.06 & 0.85 & 0.85 \\
\hline Methionine & 0.31 & 0.34 & 0.34 \\
\hline
\end{tabular}

*Viamin Premix (2.5kg/1000kg): vitamin A (15,000 U.I), vitamin D3(3,000.000 I.U) and vitamin E (30,000 I.U) vitamin k (2,500 I.U).

Thiamin B, (2,000mg), Riboflavin B2 (6,000mg). Pyridoxine B0 (4000mg) Niacin (40,000mg), vitamin B12 (20mg) panthothenic B6.

(10,000MG), Folic Acid (1,000mg), Biotin (80mg), Chlorine Chloride (500mg), Antioxidant (12g). Managaness (96g), Zinc (60g), Iron.

(24g), Copper (69), lodine (1,4g) Selenium (24g), Cobalt $(12 \mathrm{~g}) .,++=$ $2 \mathrm{~g} / \mathrm{kg}$ bioenzyme, --= No enzyme, $\mathrm{T} 1=\mathrm{O} \% \mathrm{BGO}, \mathrm{T} 2=20 \% \mathrm{BGO}, \mathrm{T} 3=$ $20 \%$ Bioenzyme added BGO.

\section{B. Experimental design/management of experimental birds}

A completely randomized design was used. One hundred and eight (108) 4 weeks old unsexed experimental broiler chicks were randomly allocated to three dietary treatments each with three replicates containing 12 birds which were fed for 28 days. Water was given ad-libitum, daily routine management activities were cleaning of pens, washing of drinker and feeders. Fresh water and feed were supplied daily.

\section{Data collection}

Haematological analysis was carried out at the end of the 28 days experimental period. Three (3) birds per treatment (one per replicate) of live weight approximate to the average weight of treatment were selected for haematological evaluation. Blood was collected during slaughter. The birds were starved of feed for 12 hours and the jugular vein was cut with a sharp knife in the early hours of morning. Two $2 \mathrm{mls}$ of blood samples were collected from the experimental birds into well labeled sterile bottles per each bird for blood profile analysis.

Carcass evaluation was also done at the end of the 28 days experiment. Three (3) birds per treatment (one per replicate) of live weight approximate to the average weight of treatment were selected for carcass evaluation. Birds were starved of feed overnight for about 12 hours before slaughter. The jugular vein was cut with a sharp knife, birds scalded in hot water for a minute, and feathers manually removed, birds were eviscerated and weighed to obtain their dressed carcass weight. The organs were removed and weighed using a sensitive electronic and micro weighing scale and grossly examined for any pathological changes. The dressed carcass weights were; eviscerated weight, dressed weight, breast weight, back weight, thighs weight, drumstick weight, wings weight, neck weight, head weight and shank weight, all expressed as relative weights on live weight. While internal organ weights were liver weight, gizzard weight, pancreas weight, spleen weight, kidney weight, abdominal fat weight, small intestine weight, large intestine weight, lungs weight, and caecum weight. These were expressed as relative weight in percentages.

All data collected were subjected to analysis of variance (ANOVA) in a completely randomized design (CRD) as

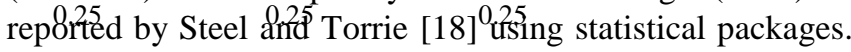
Where significant differences were observed, treatment means were separated using Duncan multiple range test [7].

\section{RESUlTS AND DISCUSSION}

The experimental diets contained $20 \%$ crude protein (Table 1) in order to meet the protein requirement of Finisher broiler chicken as recommend by NRC [16]. Similarly, metabolizable energy of the diets (2,901.36$3,091.34 \mathrm{Kcal} / \mathrm{kg}$ ), though reduced as BGO was introduced in the diets to replace part of maize and soya bean, were also within the energy requirements of finisher broiler chicken.

The effect of toasting and bioenzyme supplementation of BGO diets on live weight, carcass/internal organ characteristics of broiler finisher chicken is presented in Table 2. There were significant differences $(p<0.005)$ in the processing methods of BGO on live weight, eviscerated weight, dressed weight, back weight, drumstick weight, breast weight and thigh weights of broiler finisher chickens. Internal organ characteristics did not show any significant ( $>0.005)$ difference except for the ceacum weight which was significantly affected $(\mathrm{p}<0.005)$. Results of birds fed the test diets (either toasted or enzyme supplemented) were comparable with birds fed the control diet. The significant variation in live weight, eviscerated weight, dressed weight and most whole carcass cuts for birds fed bioenzyme supplemented BGO diets could be attributed to the effect of bioenzyme to hydrolyse non starch polysaccharides for increased energy utilization [19]. Similarly, the effect of enzyme addition is capable of eliminating or reducing the probable negative effect of anti-nutritional factors present in the test ingredient. In this experiment bioenzyme used was able to reduce the anti-nutrients in BGO and also enhance energy utilization hence the observed response.

Results of this experiment disagrees with that of Biswas et al. [5], Kidd et al. [14] and Hassan et al. [12] who reported that carcass weights were not affected due to addition of enzymes to diets of broiler finisher chickens. The non adverse effect of dietary treatments on the internal organ characteristics of broiler finisher chickens could be an indication that birds on both processing methods were able 
to cope with the level of processed BGO in the diets and or due to enhanced utilization of the test diets occasioned by the processing methods which could have probably remove the negative effect of anti-nutritional factors. Studies have shown that, caecum weight could be affected by the nature of the diet. There was a significant effect observed in the caecum weight of birds on the dietary treatments. Results of this study are in line with reports of Rehman et al. [17] who reported an increase in length and weight of caecum for birds on high fibre diets.

TABLE2: EFFECT OF PROCESSING METHODS OF BGO DIETS ON CARCASS CHARACTERISTICS OF BROILER FINISHER CHICKEN. DIETARY TREATMENTS

\begin{tabular}{|c|c|c|c|c|c|}
\hline Levels of BGO & $\mathbf{T}_{1}$ & $\begin{array}{c}20 \% \\
\text { Toasted } \\
\mathbf{T}_{2}\end{array}$ & $\begin{array}{c}20 \% \\
\text { Enzyme added } \\
\mathrm{T}_{3}\end{array}$ & SEM & $\mathbf{L S}$ \\
\hline Live weight & $1.883^{\mathrm{b}}$ & $1.852^{\mathrm{b}}$ & $2.267^{\mathrm{a}}$ & 0.271 & $*$ \\
\hline Eviscerated weight & $1.496^{\mathrm{c}}$ & $1.624^{\mathrm{b}}$ & $1.826^{\mathrm{a}}$ & 0.155 & * \\
\hline Dressed weight & $1.387^{\mathrm{c}}$ & $1.501^{\mathrm{b}}$ & $1.707^{\mathrm{a}}$ & 0.141 & $*$ \\
\hline Back weight & $297^{\mathrm{b}}$ & $290^{\mathrm{b}}$ & $337^{\mathrm{a}}$ & 0.180 & $*$ \\
\hline Thigh weight & $203^{c}$ & $238^{\mathrm{b}}$ & $260^{\mathrm{a}}$ & 0.070 & $*$ \\
\hline Drumstick weight & $194^{\mathrm{b}}$ & $233^{\mathrm{ab}}$ & $252^{\mathrm{a}}$ & 0.321 & * \\
\hline Breast weight & $424^{c}$ & $451^{\mathrm{b}}$ & $564^{\mathrm{a}}$ & 1.00 & * \\
\hline Wing weight & 143 & 165 & 170 & 0.139 & NS \\
\hline Neck weight & 76 & 83 & 77 & 0.538 & NS \\
\hline Head weight & 42 & 50 & 48 & 0.153 & NS \\
\hline Shank weight & 58 & 70 & 71 & 0.100 & NS \\
\hline Lungs weight & 11.00 & 10.76 & 10.76 & 0.833 & NS \\
\hline Liver weight & 34.33 & 34.00 & 37.33 & 0.512 & NS \\
\hline Empty Gizzard weight & 48.00 & 40.33 & 53.33 & 0.061 & NS \\
\hline Pancreases weight & 4.00 & 5.00 & 5.67 & 0.152 & NS \\
\hline Gall bladder weight & 1.67 & 2.00 & 2.67 & 0.163 & NS \\
\hline Kidney weight & 9.67 & 10.33 & 9.00 & 0.559 & NS \\
\hline Spleen weight & 1.67 & 1.67 & 1.67 & 1.00 & NS \\
\hline Heart weight & 8.00 & 8.67 & 10.67 & 0.161 & NS \\
\hline Abdomen fat weight & 22.33 & 14.33 & 20.00 & 0.344 & NS \\
\hline Small intestine weight & 83.67 & 64.67 & 76.00 & 0.280 & NS \\
\hline Large intestine weight & 3.00 & 4.00 & 4.00 . & 0394 & NS \\
\hline Caecum weight & $8.67^{\mathrm{c}}$ & $11.33^{\mathrm{b}}$ & $12.67^{\mathrm{a}}$ & 0.138 & $*$ \\
\hline
\end{tabular}

abc Rows with different superscripts are significantly different $(\mathrm{P}<0.05)$.

SEM: Standard error of mean, LS= Level of signifinance, T1 $=0 \%$ BGO,T2=20\% Toasted BGO, T3=20\% enzyme added BGO. NS=Not significant.

The effect of toasting and bioenzyme supplementation of BGO diets on haematological parameters of broiler finisher chicken is presented in Table 3. There was no significant $(p>0.005)$ variation in all haematological parameters measured. This indicates that both processing methods of BGO did not exert any adverse effect on blood constituents. Values obtained were within the normal range of haematological values for birds.

This suggests that, the subjection of BGO diets to the processing methods could have been responsible for the ability of the birds to resist infection and diseases attacks. The ceacum as internal organ characteristics is known to house some essential microbes that play important role in the health status of the bird [8]. This is shown by the significant variation in weight of ceacum in the dietary treatments which might have contributed to the improved health of the birds.

The normal haematological values observed in birds fed the test diets therefore indicates that, the inclusion of processed $\mathrm{BGO}$ in the diets could be responsible for boosting the immune system of the birds. This is in line with the reports of Joshi et al. [13] who reported that blood is a good indicator of the health of an organism. It also acts as pathological reflector of the whole body hence haematological parameters are important in diagnosing the functional status of animals exposed to toxicants. The processing methods probably may have removed or reduced the negative effect of anti-nutritional factors and toxicants.

\section{CONCLUSION AND RECOMMENDATION}

In conclusion the study revealed that both processing methods (toasting and enzyme addition) of BGO can be used at $20 \%$ BGO inclusion rate to finish broiler chickens without any adverse effect on carcass/internal organ characteristics and haematological parameters. Birds fed $20 \%$ BGO diets processed with $2 \mathrm{~g} / \mathrm{kg}$ bioenzyme diet gave higher carcass weights and is hereby recommended for finishing broiler chickens." 
TABLE 3: EFFECT OF TOASTING AND ENZYME ADDITION OF BGO DIETS ON HEMATOLOGICAL PARAMETERS OF BROILER FINISHER CHICKENS

DIETARY TREATMENT

\begin{tabular}{|c|c|c|c|c|c|c|}
\hline Levels of BGO & $0 \%$ & $\begin{array}{c}20 \% \\
\text { Toasted } \\
\mathbf{T}_{2}\end{array}$ & $\begin{array}{c}\mathbf{2 0 \%} \\
\text { Enzyme added } \\
\mathbf{T}_{\mathbf{3}}\end{array}$ & NRBP & SEM & $\mathbf{L S}$ \\
\hline PCV (\%) & 24.33 & 25.33 & 27.33 & $22-35$ & 0.186 & NS \\
\hline $\mathrm{RBC} \times 10^{9} / \mathrm{L}$ & 2.03 & 1.83 & 2.10 & $2.5-3.5$ & 0.216 & NS \\
\hline $\mathrm{WBC} \times 10^{9} / \mathrm{L}$ & 5.47 & 4.87 & 5.37 & $1.2-3.0$ & 0.346 & NS \\
\hline $\mathrm{HB}$ g/gl & 8.13 & 8.47 & 9.13 & $70-130$ & 0.267 & NS \\
\hline $\operatorname{MCV}(f l)$ & 122.10 & 102.17 & 133.70 & $90-140$ & 0.468 & NS \\
\hline $\mathrm{MCH}(\mathrm{pg})$ & 40.63 & 46.50 & 43.57 & $33-47$ & 0.324 & NS \\
\hline Lymphocytes & 49.00 & 44.67 & 45.67 & $45-70$ & 0.092 & NS \\
\hline Heterophils (\%) & 45.00 & 47.67 & 49.33 & $15-40$ & 0.341 & NS \\
\hline Eosinphils (\%) & 2.00 & 3.33 & 1.67 & $1.6-6.0$ & 0.165 & NS \\
\hline Basophil (\%) & 0.00 & 0.67 & 0.67 & - & 0.330 & NS \\
\hline Monocytes (\%) & 3.33 & 4.33 & 2.67 & $5.0-10$ & 0.177 & NS \\
\hline
\end{tabular}

SEM: Standard error of mean, LS= Level of signifinance, T1 = 0\% BGO,T2=20\% Toasted BGO, T3=20\% enzyme added BGO. NS=Not significant, $\mathrm{NRBP}=$ Normal range of blood profile value (source:jain 1993) PCV=Packed Cell Volume, RBC $=$ Red Blood Cells, WBC $=$ White Blood Cells, HB= Haemoglobin, MCV=Mean CorpscularVolume, MCH= Mean Corpscular Haemoglobin.

\section{REFERENCES}

[1] Acamovic, T, (2001). Commercial application of enzyme technology for poultry production. World's Poultry Science Journal 57:225242.acs.org

[2] Aderemi, F. A. (2004). Effects of replacement of wheat bran with cassava root sieviate supplemented or unsupplemented with enzyme on the hematological and serum biochemistry of pullets chicks. Tropical Journal of Animal Science, 7, 147-153.

[3] Adeyemo, G.O., and Longe, G.O.(2007). Effect of Graded Levels of Cottonseed cake on Performance, Hematological and carcass Characteristics of Broilers Fed from Day old to 8 Weeks of Age.African Journal Biotechnology, Vol. 6 No. 8, Pp.1064-1071.

[4] Akande, K.E. and Fabiyi, E.F, (2000). Effects of Processing Methods on some Antinutrional Factors in Legume Seeds for Poultry Feeding. International Journal of Poultry Science.9(10):996-1001.

[5] Biswal, T., Mandel, L., Sarker., S.K. (1999). Studies of Enzyme Supplementation and Herbal Preparation at Different Levels of Energy of the Performance of Broiler. J. interacademia3:53-58

[6] Doyle, D. (2006). William Hewson(1739-74). The father of hematology. British Journal of Hematology. 133(4):120-130.

[7] Duncan, D.B. (1955) Multiple Range and Multiple F-tests. A biometric Approach, 11: 1-42.

[8] Dunkley, K.D., Callyway, T.R., Chalova, V. J., Mareynolds, J,L., Humo, M.E., Dunkly, C.S., Kubena, L.F., Nisbet, D.J. and Ricke, S.C,(2009). Foodborn Samollena Ecology in the Avian Gastrointestinal Tract. Anaerobe 15:26-35.

[9] Ensminger, M.E., Oldfield, J.E. and Heinemann, W.N. (1996) Feeds and Nutrition. pp 324 -366 (The Ensminger Publishing Coy; Clovis California, USA).

[10] Enwere, N. J. (1998) Foods of Plant Origin. 301pp (Afro-Orbis Pub. Ltd. Nsukka, Nigeria). 301Pp.

[11] Gueye, E. F. (2002). Employment and income generation through family poultry in low- income food- deficit countries. World's Poultry Science Journal. Vol, 58. Pp 541-557.

[12] Hassan, HM., Aman, A., Yousse, FW., Mohamed, MA.(2011). Using Commercial Enzyme Preparation in Male and Female Broiler Fed Low Energy Diets. Egypt Journal of Animal Production 48:247-259.

[13] Joshi P. K., Bose, M. and Harish, D. (2002a) Changes in certain haematological parameters in a siluroid catfish Clarias batrachus (Linn) exposed to cadmium chloride. Pollution Researches 21 (2): 129-131.

[14] Kidd, MT., Morgan, GW., Price, CJ., Welch, PA., Fontana, EA.(2001) Enzyme Supplementation to Corn and Soyabean Meal Diets for Broiler. Applied Poultry Res. 10:65-70

[15] Microsoft Encarta, (2008). Microsoft Corporation

[16] National Research Council (NRC, 1997). Nutrient Requirements of Animal. Ninth Edition, 1994. National Academy Press Washington DC. Pp 3-127.

[17] Rehman, H., Bohon, J. and Zentek, J. (2007). Effects of differentally Fermentable Carbohydrate on the Microbial Fermentation Profile of
Gastrointestinal Tract of Broilers. Journal of Animal Physiology and Animal Nutrition 92:471-480.

[18] Steel, R. G. D. \& Torrie, J. H. (1980). Principles \& Procedures of Statistics. A Biometric Approach (2nd ed.). McGraw-Hill Publishers, New York. 633pp.

[19] Tavermari, F. C., Albino L. F. T., Morata, R. L., Dutra Junior,WM., Rostgno, HS and Viana ,MTS (2008).Inclusion of Sunflower Meal, with or without enzyme supplementation, in broiler diets. British Journal of Poultry Science 10:233-238.

[20] Tempel,V.J. and R. Aliyu, (1994). Proximate Composition of the cream coloured Decorticated Seeds of Bambara Groundnut (Voandzeia substerranea (L.) Thours). Biological Science Research Commune, 6:51-54. 